\title{
GAMBARAN KEJADIAN ANEMIA PADA IBU HAMIL DILWILAYAH KERJA PUSKESMAS SINGAPARNA TAHUN 2014
}

\author{
Oleh : \\ Purwati, S.KM,MARS \\ DR. Setiawan, M.Kes
}

\section{A. Abstrak}

Menurut WHO kejadian Anemia hamil berkisar antara 60\% dengan menetapkan $\mathrm{Hb} 11$ gr \% sebagai dasarnya. Menurut Kemenkes RI (2013) prevalensi anemia di Indonesia tergolong tinggi, hasil survei beberapa fakultas kedokteran di Indonesia pada tahun 2012 menemukan 50-63\% ibu hamil menderita anemia. Prevalensi anemia pada ibu hamil di Jawa Barat dengan peserta tes darah sebanyak 7.439 sebanyak 3050 orang (41\%) di antaranya anemia. Prevalensi anemia pada ibu hamil berdasarkan laporan Dinas Kesehatan Kabupaten Tasikmalaya tahun 2013 berkisar 3.137 orang (6,3\%) dari 43.367 orang (Dinkes Tasikmalaya, 2014). Menurut laporan KIA Puskesmas Singaparna pada tahun 2014 tidak ada kasus kematian Ibu, namun kematian bayi sebanyak 19 kasus (1,9\%) dari 990 kelahiran hidup. Sedangkan data ibu hamil yang mengalami anemia sebanyak 209 kasus (18.6\%), kasus anemia paling tinggi terdapat di Desa Singasari yaitu $36.4 \%$ dan paling rendah di Desa Sukamulya yaitu $5.1 \%$. Kasus anemia pada ibu hamil pada periode Januari-Februari tahun 2015 yaitu sebanyak 13 kasus (7.8\%) dari 167 ibu hamil. Tujuan penelitian ini mengetahui gambaran kejadian anemia pada ibu hamil.

Metode Penelitian menggunakan jenis penelitian kuantitatif dengan metode deskriptif.. Populasi dalam penelitian ini adalah seluruh ibu hamil di wilayah kerja Puskesmas Singaparna Kabupaten Tasikmalaya Tahun 2014 yaitu 1.102 orang. Tekhnik sampel menggunkaan total sampling. Tehnik pengambilan data dengan menggunakan data sekunderyang diperoleh dari buku laporan KIA Puskesmas Singaparna.Tehnik analisis data yang digunakan adalah Analisis Univariat. Analisis Univariat digunakaan untuk mengetahui proporsi dari masing-masing faktor-faktor yang berhubungan dengan anemia dalam kehamilan.

Berdasarkan tabel diatas didapatkan bahwa ibu hamil yang mengalami anemia di wilayah Kecamatan Singaparna pada tahun 2014 sebanyak 209 kasus (18.6\%). Adapun kasus anemia paling tinggi terdapat di Desa Singasari yaitu $36.4 \%$ dan paling rendah di Desa Sukamulya yaitu 5.1\%.

Ibu hamil dapat melakukan konseling secara pro aktif ke petugas kesehatan mengenai komplikasi kehamilan dan ibu dapat mengkonsumsi tablet Fe secara teratur dan makanan yang bergizi. Serta sebaiknya bidan meningkatkan pelayanan pada ibu hamil melalui optiomalisasi kelas ibu hamil sehingga penyuluhan tentang anemia, gizi akan lebih mudah untuk dilakukan.

\section{Kata Kunci: Anemia, Ibu Hamil}




\section{B. Latar Belakang}

Angka Kematian Ibu (AKI) dan Angka Kematian Bayi (AKB) merupakan masalah yang menjadi prioritas di bidang kesehatan, World Health Organization (WHO) memperkirakan di seluruh dunia AKI mencapai 500.000 jiwa pertahun. Menurut hasil Survei Demografi Kesehatan Indonesia (SDKI) Angka Kematian

Ibu di Indonesia tahun 2012 sebesar 359 per 100.000 kelahiran hidup, dan Angka Kematian Bayi mencapai 32 per 1.000 kelahiran hidup, Angka Kematian Anak Balita 44 per 1000 kelahiran hidup dan Angka kematian Neonatus 19 per 1000 kelahiran hidup.

AKI di Jawa Barat mengalami penurunan dari tahun 2012 sampai tahun 2013 dimana pada tahun 2012 AKI sebesar 309 per 100.000 kelahiran hidup,

sedangkan pada tahun 2013 AKI sebesar 74 per 100.000 kelahiran hidup (Dinkes Jabar, 2011). Menurut data Dinas Kesehatan Kabupaten Tasikmalaya pada tahun

2013, AKI mengalami penurunan yaitu 36 orang per 100.000 kelahiran hidup, sedangkan pada tahun 2012 sebanyak 60 per 100.000 kelahiran hidup.

Penyebab utama kematian ibu yaitu perdarahan (42\%), infeksi (10\%), hipertensi dalam kehamilan (13\%), partus macet (9\%) dan aborsi (11\%) (Saifuddin, 2010). Penyebab utama kematian maternal antara lain perdarahan postpartum (disamping eklampsia dan penyakit infeksi) dan plasenta previa (Arisman, 2008). Adapun fakor penyebab kematian ibu tidak langsung

diantaranya adalah anemia dan kurang energi kronik (KEK).

Anemia ibu hamil adalah suatu keadaan dimana adanya penurunan kadar hemoglobin hematokrit dan jumlah eritrosit pada ibu hamil di bawah nilai $11 \mathrm{gr} \%$,
Anemia yang sering dijumpai dalam kehamilan adalah anemia karena kekurangan

zat besi (fe) sehingga lebih dikenal dengan istilah anemia gizi besi (AGB).

Menurut WHO kejadian Anemia hamil berkisar antara 60\% dengan menetapkan $\mathrm{Hb} 11$ gr \% sebagai dasarnya. Menurut Kemenkes RI (2013) prevalensi anemia di Indonesia tergolong tinggi, hasil survei beberapa fakultas kedokteran di Indonesia pada tahun 2012 menemukan $50-63 \%$ ibu hamil menderita anemia. Prevalensi anemia pada ibu hamil di Jawa Barat dengan peserta tes darah sebanyak 7.439 sebanyak 3050 orang (41\%) di antaranya anemia.

Prevalensi anemia pada ibu hamil berdasarkan laporan Dinas Kesehatan Kabupaten Tasikmalaya tahun 2013 berkisar 3.137 orang $(6,3 \%)$ dari 43.367

orang (Dinkes Tasikmalaya, 2014). Menurut laporan KIA Puskesmas Singaparna

pada tahun 2014 tidak ada kasus kematian Ibu, namun kematian bayi sebanyak 19 kasus (1,9\%) dari 990 kelahiran hidup. Sedangkan data ibu hamil yang mengalami anemia sebanyak 209 kasus (18.6\%), kasus anemia paling tinggi terdapat di Desa Singasari yaitu $36.4 \%$ dan paling rendah di Desa Sukamulya yaitu $5.1 \%$. Kasus anemia pada ibu hamil pada periode Januari-Februari tahun 2015 yaitu sebanyak 13 kasus (7.8\%) dari 167 ibu hamil.

Melihat dari gambaran data di atas, anemia merupakan masalah yang memerlukan penanganan serius, karena anemia hamil disebut juga "Potential Danger to Mother and Child" (potensial membahayakan ibu dan anak).

Penanganan anemia hamil itu sendiri bukan hanya melibatkan tenaga kesehatan

saja tapi juga semua pihak yang terkait termasuk ibu hamil dan keluarga sehingga terbentuk hubungan yang baik dan ibu 
memiliki pengetahuan yang cukup juga mau melakukan pemeriksaan kehamilan

\section{Metode Penelitian}

Metode Penelitian menggunakan jenis penelitian kuantitatif dengan metode deskriptif.. Populasi dalam penelitian ini adalah seluruh ibu hamil di wilayah kerja Puskesmas Singaparna Kabupaten Tasikmalaya Tahun 2014 yaitu 1.102 orang. Tekhnik sampel menggunkaan total sampling.

Tehnik pengambilan data dengan menggunakan data sekunderyang diperoleh dari buku laporan KIA Puskesmas Singaparna.

Tehnik analisis data yang digunakan adalah Analisis Univariat. Analisis Univariat digunakaan untuk mengetahui proporsi dari masing-masing faktorfaktor yang berhubungan dengan anemia dalam kehamilan.

\section{Hasil Penelitian}

Berdasarkan hasil penelitian menyatakan bahwa gambaran kejadian anemia pada ibu hamil di wilayah Puskesmas Singaparna Kabupaten Tasikmalaya tahun 2014 adalah sebagai

\section{E. Pembahasan}

Berdasarkan hasil penelitian didapatkan bahwa angka kejadian anemia pada ibu hamil di wilayah Kecamatan Singaparna pada tahun 2014 sebanyak 209 kasus (18.6\%).

Anemia dalam kehamilan adalah kadar hemoglobinnya kurang dari $11 \mathrm{gr} \%$. Anemia pada trimester kedua saat kadar hemoglobinnya kurang dari 10,5 gr\% dan anemia pada trimester satu dan ketiga saat kadar hemoglobinnya kurang dari 11 gr\% (Manuaba, 2008). Anemia adalah suatu keadaan adanya penurunan kadar hemoglobin hematokrit dan jumlah eritrosit di bawah nilai normal. Pada penderita anemia, lebih sering disebut kurang darah, kadar sel darah merah (hemoglobin atau HB) di bawah nilai normal. rutin, konsumsi tablet $\mathrm{Fe}$ dan makanan yang bergizi.

berikut :

Kasus Anemia Pada Ibu Hamil Di

Wilayah Kerja Puskesmas Singaparna Tahun 2014

\begin{tabular}{clcc}
\hline No & \multicolumn{1}{c}{ Desa } & Jumlah & $\%$ \\
\hline 1 & Singasari & 47 & 36,4 \\
\hline 2 & Singaparna & 30 & 16,9 \\
\hline 3 & Sukamulya & 4 & 5,1 \\
\hline 4 & Cipakat & 10 & 6,6 \\
\hline 5 & Sukaasih & 8 & 8,7 \\
\hline 6 & Cintaraja & 55 & 29,1 \\
\hline 7 & Cikunir & 30 & 16,5 \\
\hline 8 & Cikadongdong & 25 & 19,8 \\
\hline & Jumlah & 209 & 18,6 \\
\hline
\end{tabular}

Berdasarkan tabel diatas didapatkan bahwa ibu hamil yang mengalami anemia di wilayah Kecamatan Singaparna pada tahun 2014 sebanyak 209 kasus (18.6\%). Adapun kasus anemia paling tinggi terdapat di Desa Singasari yaitu $36.4 \%$ dan paling rendah di Desa Sukamulya yaitu $5.1 \%$.

WHO menetapkan anemia dalam kehamilan adalah kondisi ibu dengan kadar HB di bawah 11 gr\% pada trimester I dan III atau kadar HB <10,5 gr\% pada trimester II. Kebutuhan gizi bagi ibu hamil pada masa kehamilan memerlukan tambahan zat besi untuk meningkatkan jumlah sel darah merah dan membentuk sel darah merah janin juga plasenta sebagai gambaran berapa banyak kebutuhan zat besi pada kehamilan adalah sebagai berikut:

\begin{tabular}{llrr}
\hline $\begin{array}{l}\text { 1. } \begin{array}{l}\text { Meningkatkan } \\
500 \mathrm{mg} \mathrm{Fe}\end{array} \\
\text { Sel }\end{array}$ & Darah & Ibu \\
\hline $\begin{array}{l}\text { Terdapat } \\
300 \mathrm{mg} \mathrm{Fe}\end{array}$ & dalam & plasenta \\
\hline 3. Untuk & darah & janin \\
& & \\
\hline & $\begin{array}{l}\text { Jumlah kebutuhan zat besi pada ibu hamil } \\
\text { adalah 900 mg Fe }\end{array}$ \\
\hline
\end{tabular}


Jika persediaan cadangan $\mathrm{Fe}$ minimal, maka setiap kehamilan akan menguras persediaan $\mathrm{Fe}$ tubuh dan akhirnya menimbulkan anemia pada kehamilan berikutnya. Pada kehamilan, relatif terjadi anemia karena darah ibu hamil mengalami pengenceran dengan peningkatan volume $30 \%-40 \%$ yang puncaknya pada kehamilan 32-34 minggu. Jumlah peningkatan sel darah 18\%-30\% dan hemoglobin sekitar 19\%. Kebutuhan zat besi pada wanita hamil yaitu rata-rata mendekati $800 \mathrm{mg}$. Kebutuhan ini terdiri dari, sekitar $300 \mathrm{mg}$ diperlukan untuk janin dan plasenta serta $500 \mathrm{mg}$ lagi digunakan untuk meningkatkan massa haemoglobin maternal. Kurang lebih 200 mg lebih akan dieksresikan lewat usus, urin dan kulit. Makanan ibu hamil setiap 100 kalori akan menghasilkan sekitar 8-10 mg zat besi. Perhitungan makan 3 kali dengan 2500 kalori akan menghasilkan sekitar 20-25 mg zat besi perhari. Selama kehamilan dengan perhitungan 288 hari, ibu hamil akan menghasilkan zat besi sebanyak $100 \mathrm{mg}$ sehingga kebutuhan zat besi masih kekurangan untuk wanita hamil.

Banyak faktor yang berhubungan dengan anemia pada ibu hamil diantaranya gizi, penyakit infeksi, sosial ekonomi, gangguan absorpsi, pendidikan, pengetahuan dan lain lain.

Menurut Manuaba (2006) pengaruh

\section{F. Simpulan dan Saran}

Berdasarkan penelitian didapatkan bahwa ibu hamil yang mengalami anemia di wilayah Kecamatan Singaparna pada tahun 2014 sebanyak 209 kasus (18.6\%). Adapun kasus anemia paling tinggi terdapat di Desa Singasari yaitu $36.4 \%$ dan paling rendah di Desa Sukamulya yaitu 5.1\%.

Sebaiknya ibu hamil dapat melakukan konseling secara pro aktif ke petugas kesehatan mengenai komplikasi kehamilan dan ibu dapat mengkonsumsi tablet $\mathrm{Fe}$ secara teratur anemia adalah sebagai berikut :

1. Bahaya selama kehamilan

a. Dapat terjadi abortus

b. Persalinan prematur

c. Hambatan tumbuh kembang janin dan rahim

d. Mudah terjadi infeksi

e. Ancaman decompensasi cordis $(\mathrm{Hb}$ $<6$ gr\%)

f. Mola Hidatidosa

g. Hyperemesis gravidarum

h. Perdarahan Antepartum

i. Ketuban pecah dini

2. Bahaya saat persalinan

a. Gangguan HIS dan kekuatan mengedan

b. Kala I dapat berlangsung lama

c. Kala II dapat berlangsung lama sehingga melelahkan

d. Kala III dapat terjadi retensio plasenta dan perdarahan postpartum karena atonia uteri

e. Kala V dapat terjadi perdarahan postpartum sekunder dan atonia uteri

3. Bahaya Saat Nifas

a. Terjadi Sub Involusi Uteri

b. Memudahkannya infeksi puperium

c. Pengeluaran ASI berkurang

d. Terjadi dekompensasi kordis mendadak setelah persalinan

dan makanan yang bergizi .Sebaiknya bidan meningkatkan pelayanan pada ibu hamil melalui optiomalisasi kelas ibu hamil sehingga penyuluhan tentang anemia, gizi akan lebih mudah untuk dilakukan.

Bagi tim medis, perlu melakukan upaya pencegahan anemia pada ibu hamil dengan mengobati penyakit yang dapat memperberat anemia pada ibu hamil. Perlu adanya upaya dalam mendeteksi sedini mungkin kepada ibu risiko tinggi mengalami komplikasi anemia. Meningatkan pelayanan 
melalui program gizi, mencegah anemia sebagai upaya dalam mencegah komplikasi pada

\section{G. Referensi}

Arifin, MD 2007. Kurang Gizi pada Ibu Hamil: Ancaman pada Janin. Dari

http://www.infomedika.coai [ 29 Febaruari 2015]

Arisman, 2008. Gizi dalam Daur Kehidupan, Jakarta. Penerbit EGC Depkes RI (2013. Kematian ibu di Indonesia

Djamilus (2007. Anemia dalam kehamilan.

http://www.mediacastore.com [24Februari 2015]

dr. Zhafran, 2012. Anemia pada Kehamilan. $\quad$ http:// Zhafran.worpress.com[2

Febaruari 2015;

Husaini. 2004. Husaini, 2004.

Prevalensi kekurangan Darah pada wanita. Dari

http://www.mediaindonesia.net. [25 Februari Maret 2015] kehamilan, persalinan dan nifas serta bayi BBLR.

Indrawati, 2010. Panduan Perawatan Kehamilan. Jogjakarta. Atma Media Press

Manuaba, 2008. Ilmu Kebidanan dan Keluarga Berencana untuk Pendidikan Bidan. EGC. Jakarta.

Proverawati, Proverawati. 2011. Ilmu Gizi untuk Keperawatan dan Gizi Kesehatan.

Nuha Medika. Jakarta.

Saifuddin. 2010. Ilmu Kebidanan. Jakarta. Yayasan Bina, Pustaka, Sarwono Prawirohardjo. Jakarta SDKI. Angka Kematian Ibu dan Bayi Masih Tinggi. http://www.depkes.go.iddiakses[12

Febaruai2015]

Soekirman, 2000. Gizi dan Anemia. http://www.kompas.com diakses tanggal 